\title{
From Reading Books to Sharing Books: Going Beyond the Virtuous Circle of the Good Reader
}

\section{Kunitaro Mizuno}

\author{
Fukuoka Prefectural University, Japan
}

The "virtuous circle of the good reader" (Nuttall, 2006, p.127) is considered the key to the success of extensive reading. Teachers make efforts to create the virtuous circle in the act of reading for each student. From the point of individual reading, this works well. From the point of designing a class where students learn collaboratively, the virtuous circle needs something extra. This paper would argue that from the perspective of self-determination theory, it is indispensable to incorporate dialogue with others into the virtuous circle. To implement the idea, the IRC (Interactive Reading Community) Project has been carried out. The results of student questionnaires are analyzed using reader-response theory to see the effect that others have. Also, from the perspective of general education, how reading books in the IRC Project can foster learning culture (Dewey, 1915) is examined.

多読の授業を実践するうえで「読書の好循環 (Nuttall, 2005)」が鍵を 握つていると考えられており、教師はそれを生み出すために様々な努力 を重ねている。その好循環は、「個人」を単位とした読書活動の指針とし て有益である。しかし、授業を「他者との協同的な学びの実践」として捉 えると、その好循環にプラス 者との出会いと対話」が必要であることを、Deci \& Ryan (1996)の「自己 決定理論」の観点から議論する。そして、「他者」のいる読書環境を教室 とインターネット上に創出してきた IRC(Interactive Reading Community) Project を紹介する。その教育的効果をアンケート結果で示し、2つの観 点から考察する。1つは「読者反応理論」から、もう1つは「一般教育」の 英語の授業において「教養 (Dewey，1915)」を豊かにする観点から考察 する。

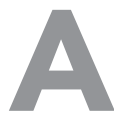

s Nuttall (2006) shows in Figure 1, if a teacher can provide appropriate books for students and help them choose what to read, they will read faster, read more, understand better, and enjoy reading. This paper will develop the cognitive cycle from the point of social aspects of reading at a Japanese university.

\section{Small Amounts of English in Textbooks}

It has long been said that although Japanese people learn English for six years from junior to senior high school, they cannot utilize English as a means of communication. This criticism has led the Educa-

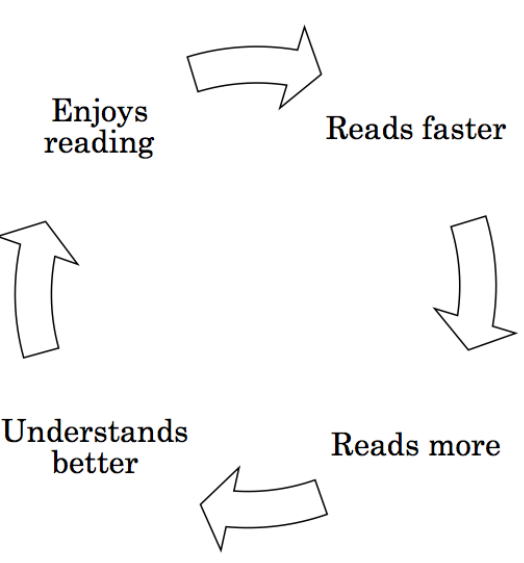

Figure 1. The Virtuous Circle of the Good Reader

tion Ministry to incorporate learning English into the curriculum of elementary school education since 2011. Putting aside the arguments for and against starting to learn English before junior high school, the fact was pointed out that the amount of English provided in the authorized school textbooks for six years was very small. According to the editorial department of Modern English Education (1996), if we printed the words of the New Horizon series in a paperback book, the total number of English words read by junior high school students would be equivalent to 19 pages. Okumura (1999) also pointed out that if we printed the words of the Unicorn series in a paperback book, the English words read by high school students would be equivalent to 138 pages. As a total for six years, 157 pages were read. Since a paperback usually has about 250 pages, about $60 \%$ of one paperback is read during the six years. It means that an average of 26 pages is read every year and about 2 pages are read per month. This naturally has made teachers in Japan consciously provide students with more reading material in English in addition to the authorized school textbooks. 


\section{Cognitive Approach}

In the context of searching for how to increase Japanese students' English input, the Input Hypothesis proposed by Krashen (1985) has been laid out as a theoretical foundation for extensive reading. He argued that "humans acquire language in only one way-by understanding messages, or by understanding 'comprehensible input"'(p. 2). This view can be visualized in Figure 2 (Masamura, 2012, p. 12):

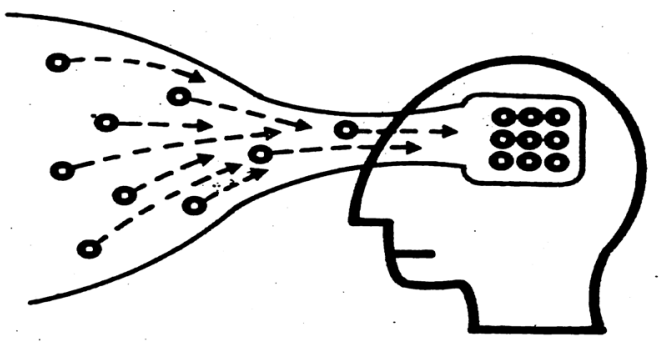

Figure 2. Visual Image of the Input Hypothesis and Cognitive Approach ${ }^{1}$

As the image shows, the Input Hypothesis considers learning as an internalized cognitive process bound inside individual heads, which comes from the information processing model in computer science-input and output-from the 1970s (McLaughlin, 1987; Shiffrin \& Schneider, 1977). This view of learning a language is called the cognitive approach.

Krashen (1993) also suggested that Free Voluntary Reading (FVR) is the best way to implement the idea. Mason and Krashen (1997) conducted an experiment showing the efficacy of this method. They compared a FVR class where students read books during and outside the class and listened to stories read aloud by the teacher in class with another class which adopted the grammar-translation method. Both classes took a cloze test at the beginning of the semester and at the end of the semester. The growth rate of the scores of the students in the grammar-translation method class was half of those of the FVR class. Mason $(2006,2011)$ also showed that a FVR class was effective to improve vocabulary, grammar, and writing, as well as reading, and improved the scores of the TOEIC and TOEFL tests.

Furthermore, to enhance the hypothesis of comprehensible input through reading books extensively, Sakai and Kanda (2005) advocated it in their book titled, Kyoshitsude yomu eigo hyakumango: tadokujugyo no susume [Reading one million words in the classroom: encouragement for extensive reading]. Their book marked the beginning of the method of extensive reading in Japan. Also,
Takase (2008) implemented SSR (Sustained Silent Reading), which gives students as much time as possible for concentrating on reading during the class, and gives teachers time for giving helpful advice for students on the spot. It also includes students continuing reading inside and outside class to reach the goal of one million words. The SSR advocates like to witness, as Henry (1995) describes it, "the most beautiful silence on earth, that of students engrossed in their reading" (p. xv).

\section{Review of the Virtuous Circle}

The common factors behind the popularity and success of both FVR and SSR methods can be clearly explained in the fulfillment of the "virtuous circle of the good reader" as Nuttall (2006) shows in Figure 1.

When it comes to motivation, however, we should also examine the virtuous circle with reference to the self-determination theory proposed by Deci and Ryan (1996). They argue that as fundamental sources for humans to be motivated to learn, the following three psychological needs should be satisfied: autonomy, competence, and relatedness. There are many experimental studies which show that satisfying the three psychological needs motivated their students to learn English (e.g., Hiromori, 2006; Noels, Pelletier, Clement and Vallerand, 2000; Sakai \& Koike, 2008).

From the perspective of the three psychological needs, the FVR and SSR methods include autonomy and competence. Students can choose what they want to read autonomously and they also feel that they are competent readers (they are able to enjoy reading English books). As for the relatedness of the self-determination theory, both the FVR and SSR methods do not consider the relationships of students as playing an important role to motivate their act of reading. It is clear that the virtuous circle in Figure 1 lacks relatedness and exclusively focuses on the cognitive process of reading.

Unlike the FVR and SSR methods, over the past 10 years, it has gradually become increasingly popular for students to be encouraged to read more by relating what they read to other language skills, such as listening, speaking, and writing and interacting with their classmates during the class. Extensive Reading Activities for Teaching Language (Bamford \& Day, 2004) and New Ways in Teaching Reading (Day, 2012) have collections of classroom activities for extensive reading. However, since the priority of the extensive reading class is strictly a large quantity of input from reading books, interaction with others is not regarded as an essential element in the virtuous circle of the good reader. 


\section{Interactive Reading Community Project}

I would argue that relatedness, that is, interaction with others, should be incorporated into the virtuous circle to enrich students' reading experiences and further facilitate their act of reading. In order to justify my thesis, I would like to present the Interactive Reading Community (IRC) Project, which was created and has been utilized since 1999 (Mizuno, Kawakita, Toya, \& Nishino, 2011; Mizuno, Toya, Kawakita, \& Nishino, 2013; Mizuno, 2013). To clarify the interactive nature of the IRC project, the whole idea of the IRC project can be visually described by the Doughnut Theory for Learning (Saeki, 1995).

The Doughnut Theory claims that there are three phases in the process of learning at school: the I-phase, the YOU-phase, and the THEY-phase (Figure 3). The I-phase signifies the learning process of a student. The YOU-phase signifies the interaction with classmates and a teacher. The THEY-phase signifies people in the outer world surrounding the world of $\mathrm{I}$ and YOU (WE). Figure 3 shows that when learning expands from I to YOU and from WE to THEY, the student will move through the first interface and the second interface. In the context of the IRC project, the first interface indicates a classroom where I see YOU face-to-face and introduce our favorite books to each other. The second interface indicates the IRC website <http://www.interactive-l-community. com/IRC5/Login.php> where WE can read reaction reports about books posted by THEY who are students at other universities on the IRC website, and ordinary readers who post their reviews on <amazon. co.jp > and <amazon.com>.

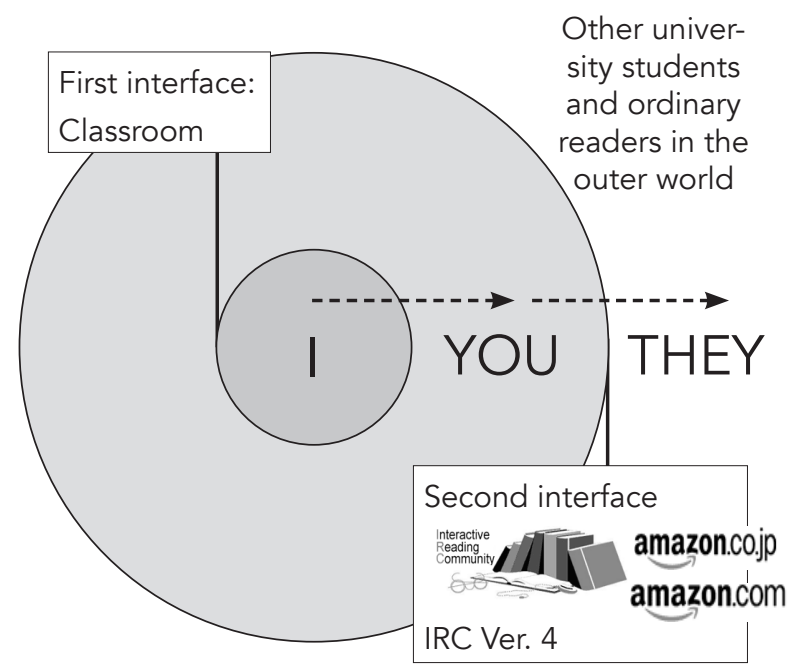

Figure 3. The Structure of the IRC Project from the Perspective of the Doughnut Theory for Learning (Mizuno, Toya, Kawakita, \& Nishino, 2013)
In 2011, questionnaires were given to 434 students who joined the IRC project from five universities. The results were analyzed from the perspective of a sociocultural approach (Mizuno et al., 2013). I will reexamine the questionnaire data focusing on how relatedness (interaction with others in the classroom and on the IRC website) could facilitate the virtuous circle and enrich their reading experiences in the IRC project.

\section{Students' Attitude}

The existence of others at the first interface (in the classroom) and at the second interface (the IRC website) changed students' attitude toward reading and had a positive impact on the cognitive process of reading. $98.1 \%$ of the students believed that since they had to discuss books they read with those in the classroom and on the IRC website who had not read them yet, they began to read books keeping others in mind while thinking about the story line and the details of the story. $89.6 \%$ answered that they reflected on the scenes and English expressions that made an impact on them, so they could share them with others in the classroom and on the IRC website.

\section{Students' First Interaction}

Students read one book every week. In groups of four, they introduced the book they had read to their classmates. $81.7 \%$ found the book talk very helpful when choosing books to read. The introduction and information about the books they were given helped them read more fluently and have a better understanding. $84.3 \%$ also thought that being part of a reading community encouraged them to continue reading.

\section{Students' Second Interaction}

As for writing reaction reports, using the Japanese language is key to making valuable shared reading experiences. As Cook (1992) insists on multicompetence, where the mother tongue always exists in the learners' minds, it would be unnatural and sometimes inefficient for students not to use the Japanese language as a learning tool. It is their mother tongue that enables them to appreciate and think deeply about the stories and fully express their ideas and feelings. $89.1 \%$ perceived that through writing reaction reports they could better understand and discuss the books. $92.6 \%$ also thought that writing about books they had read was essential to prepare for small group classroom discussions. 
The most distinct feature of the IRC website at the second interface is that the IRC version 4 contains about 100,000 reaction reports and comments that have been posted since 2010. Students can access this rich database and read reaction reports posted in the past by THEY who were students from other classes and other universities. 95.9\% believed that reading several reaction reports posted for one particular book made them realize that there were many interpretations of the book. In this way, writing and reading and sharing on the IRC website at the second interface has provided cognitive and mental development for each student.

\section{Reader-Response Theory}

As the analysis of the questionnaires (Mizuno et al., 2013) indicates, students who join the IRC project will interpret as well as comprehend (read faster, read more, understand better, and enjoy reading) the text in the book better due to writing a reaction report (not a summary) about the book for other members of the IRC project. In other words, they go beyond the virtuous circle of the good reader. This situation makes a big difference between reading texts for the University English Entrance Exam and reading books as a member of the IRC project. Looking closely at the differences between the two, there is significant educational value to participating in the IRC project upon entering a university.

When we examine the act of reading and reading ability, it is essential to consider two aspects of reading: comprehension and interpretation (Urquhart, 1987). When it comes to taking an examination, however, comprehension is focused on exclusively. In order to pass the university entrance examination, high school students are entirely engaged in answering questions with only one right answer. In other words, the test giver removes the relationship between the student and the writer. High school students are only examinees and not considered autonomous readers. This situation is severely criticized by Widdowson (1979):

Comprehension questions, for example, commonly require the learner to rummage around in the text for information in a totally indiscriminate way, without regard to what purpose might be served in so doing. Learners are seldom required to use the information they acquire, either within an interaction process to facilitate access to the most salient directions towards meaning or to follow these directions into their own conceptual worlds. Reading is thus repre- sented as an end in itself, an activity that has no relevance to real knowledge and experience and therefore no real meaning. (p. 180)

Thus, it is pedagogically essential that when Japanese students enter a university, they should learn another aspect of reading, which is to relate what they read to their own world of knowledge and experiences, and be encouraged to ask questions and give their opinions. They should also learn to consider reading as social as well as cognitive by utilizing the information and ideas in the books and doing something relevant with others after reading.

Needless to say, interpreting and evaluating text differs from person to person (Carrell, Devine, \& Eskey, 1988). This interactive approach to reading follows the reader-response theory. Hirvela (1996) succinctly describes the notion of the reader-response theory:

A reader's response to a text is a 'story of reading,' and that in discussing it the reader will 'tell a story of reading.' That is, the reader's interpretation of the text describes not the text itself but how the reader re-created it while reading it. It is, then, the reader and his or her reading process that we encounter when an interpretation of a text is supplied. (p. 128)

Telling a story of reading is exactly what the students in the IRC project learn to do both in the book talk during the class and in writing a reaction report. According to the results of the questionnaires, the existence of "others" in the classroom and on the IRC website played an important role. Since they needed to explain books to others and wanted to entice them to read their favorite books, inevitably they were motivated and their understanding of the text was significantly deepened. To promote the books they enjoyed, they were more thoughtful when writing their reaction reports.

\section{Conclusion}

Contrary to the visual image of the cognitive approach in Figure 2, the approach taken by the IRC project is called the sociocultural approach, which considers learning as a mediated process where individuals increase their cognitive development interacting with cultural tools such as language and artifacts (Mizuno et al, 2013). This view of learning can be visualized in Figure 4 (Masamura, 2012, p. 396): 


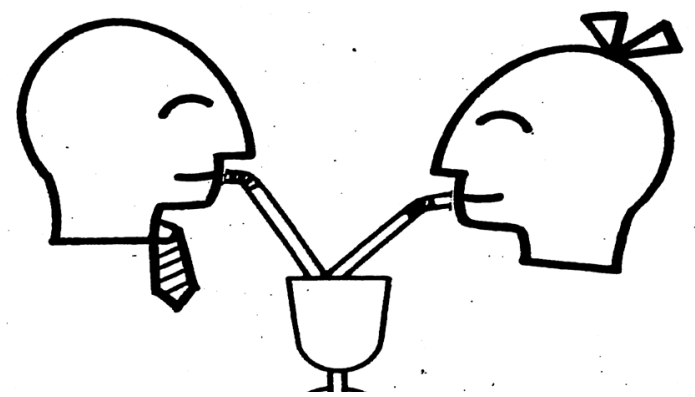

Figure 4. Visual Image of the Sociocultural Approach to Learning a Language ${ }^{1}$

The straws are tools (IRC website, Japanese language, and English language) which mediate between the two people and enable them to share the contents of the glass (books) with each other. Clearly, the best characteristic of the sociocultural approach is sharing, making the IRC project special compared with the cognitive-based FVR and SSR methods.

Finally, what must not be forgotten is that most extensive reading classes in Japan are offered to freshmen and sophomores as part of the general education curriculum. From the perspective of general education where students learn culture, including humanities, natural science, social science, health science, and language, the IRC project should be examined to see how it makes a contribution to learning culture.

Dewey (1915) defines culture as the "growth of the imagination in flexibility, in scope, and in sympathy" (p. 56). Culture etymologically means the tilling of land. To learn culture can be interpreted as cultivating our minds and hearts in an educational context. Putting Dewey's idea about culture and the etymological meaning of culture at the center of general education, a reading class can create an environment where students can cultivate their

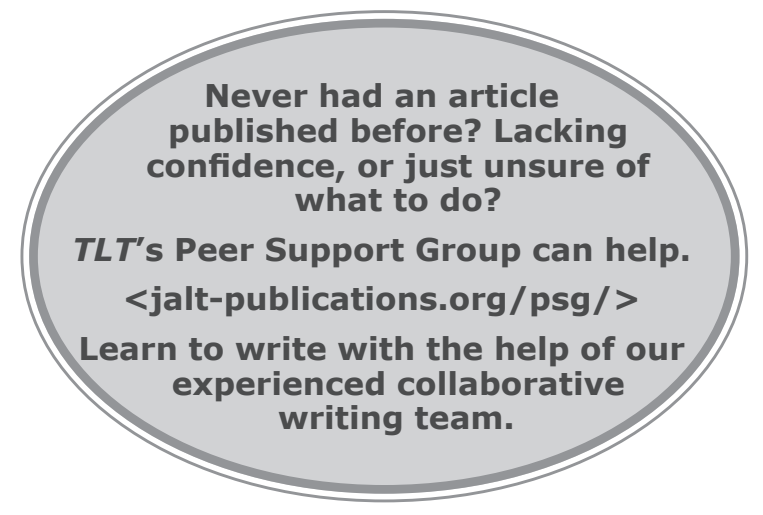

minds and hearts through reading experiences, allowing their imaginations to grow. To this end, students should not only read alone but also should have interaction with others helping them cultivate their minds and hearts and see the world from multiple perspectives. In this respect, the IRC project has been designed and practiced to have cultivated students' reading experiences collaboratively and produced positive results as the analysis of the questionnaires (Mizuno et al., 2013) distinctly show. The IRC project will continue cultivating students' minds and hearts through not only having them read books in the virtuous circle but also through interactions with others utilizing the Japanese language to deepen their understanding of the contents of books and each other.

\section{Endnotes}

1. Figure 2 and Figure 4 are each originally an image of the words account and share. in An illustrated dictionary of English words. (Masamura, 2012).

\section{References}

Bamford, J., \& Day, R. R. (Eds.). (2004). Extensive reading activities for teaching language. Cambridge: Cambridge University Press.

Carrell, P., Devine, J., \& Eskey, D. (Eds.). (1988). Interactive approaches to second language reading. Cambridge: Cambridge University Press.

Cook, V. J. (1992). Evidence for multi-competence. Language Learning, 42(4), 557-591.

Day, R. R. (Ed.). (2012). New ways in teaching reading. Virginia: TESOL International Association.

Deci, E. L., \& Ryan, R. M. (1996). Why we do what we do: Understanding self-motivation. New York : Penguins Books.

Dewey, J. (1915). The school and society. Chicago: University of Chicago Press.

Henry, J. (1995). If not now: Developmental readers in the college classroom. Portsmouth, NH: Boynton/Cook, Heinemann.

Hiromori, T. (2006). The effects of educational intervention on $\mathrm{L} 2$ learners' motivational development. JACET Bulletin, 43, 1-14.

Hirvela, A. (1996). Reader-response theory and ELT. ELT Journal, 50(2), 127-134.

Krashen, S. (1985). The input hypothesis: Issues and implications. Culver City, CA: Language Education Associates.

Krashen, S. (1993). The power of reading. Englewood, CO: Libraries Unlimited.

Masamura, H. (2012). An illustrated dictionary of English words. Tokyo: Kokusai Gogakusha. 
Mason, B., \& Krashen, S. (1997). Extensive reading in English as a foreign language. System, 25(1), 91-102.

Mason, B. (2006). Free voluntary reading and autonomy in second language acquisition: Improving TOEFL scores from reading alone. International Journal of Foreign Language Teaching, 2(1), 2-5.

Mason, B. (2011). Impressive gains on the TOEIC after one year of comprehensible input, with no output or grammar study. The International Journal of Foreign Language Teaching, 7(1), 1-5. Retrieved from <http:// www.tprstories.com/ijflt/articles-winter-2011/Mason_ Tanaka_IJFLT_11-11.pdf>

McLaughlin, B. (1987). Theories of second language learning. London: Edward Arnold.

Mizuno, K., \& Editorial department of ALC Press (Ed.). (2010). Daigakusei ni nattara yosho o yomo [Let's read English books when you become a university student]. Tokyo: ALC Press.

Mizuno, K., Kawakita, N., Toya, M., \& Nishino, H. (2011). Project IRC: Tadokunojugyo niokeru gokeitekina dokushokankyou no soshutsu [Project IRC: Creating a Reciprocal Reading Environment in an Extensive Reading Class]. Language Education \& Technology, 48, 143-171.

Mizuno, K., Toya, M., Kawakita, N., \& Nishino, H. (2013). Project IRC: Tadokunojugyo niokeru shakaibunkateki apurouchi no kouka [Project IRC: Effects of the Sociocultural Approach in Extensive Reading Classrooms]. Language Education \& Technology, 13, 41-69.

Mizuno, K. (2013). Creating "Reading Circles" in the classroom and on the Internet. In R. R. Day (Ed.), New Ways in Teaching Reading, revised (pp. 36-37). Alexandria, VA: TESOL International Association.

Modern English Teaching. (1996, May). Study on the quantity of English Education. Modern English Teaching, 33-36.

Noels, K. A., Pelletier, L. G., Clement, R., \& Vallerand, R. J. (2000). Why are you learning a second language? Motivational orientations and self-determination theory. Language and Learning, 50, 57-85.
Nuttall, C. (2006). Teaching reading skills in a foreign language (3rd ed.). Oxford: MacMillan.

Okumura Y. (1999). Kokojidai ni bokuraga yomu eibun wa koreppochi? [What small amounts of English high school students read in Japan!]. In Editorial department of ALC Press (Ed.). Do it! (pp.74-75). Tokyo: ALC.

Saeki, U. (1995). 'Manabu' toiukoto no imi [The meaning of learning]. Tokyo: Iwanami Shoten.

Sakai, K., \& Kanda, M. (2005). Kyoshitsude yomu eigo hyakumango: tadokujugyo no susume [Reading one million words in the classroom: encouragement for extensive reading]. Tokyo: Taishukan Shoten.

Sakai, H., \& Koike, H. (2008). Changes in Japanese university students' motivation to learn English: Effects of volunteering in an international event. JALT Journal, 30 (1), 51-67.

Schneider, W., \& Shiffrin, R. M. (1977). Controlled and automatic human information processing: I. Detection, search, and attention. Psychological Review, 84, 1-66.

Smith, F. (1985). Reading without nonsense (2nd ed.). New York: Teachers College Press.

Takase, A. (2008). Yarukio okosaseru jugyonaitadoku [SSR for Reluctant Learners to Read]. Kinki University English Journal, 2, 19-36. The Kinki University English Society.

Urquhart, A. H. (1987). Comprehensions and Interpretations. Reading in a Foreign Language, 3, 387-409.

Widdowson, H. G. (1979). Explorations in Applied Linguistics. Oxford: Oxford University Press.

\section{Kunitaro Mizuno is an as-} sociate professor at Fukuoka Prefectural University. His research interests are creating a learning community utilizing ICT, data-driven learning, learner's dictionary, and pedagogical grammar.

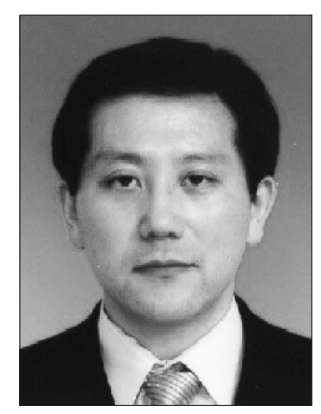

\section{A Kyushu Special—Vocabulary on Saturday, Extensive Reading on Sunday}

\author{
4th Annual Vocabulary Symposium \\ Presented by the JALT Vocabulary SIG \\ Saturday, June 20, 2015 \\ Kyushu Sangyo University \\ Featured discussants: \\ Dr. Stuart Webb and Dr. Rie Koizume \\ For more information:
}

The JALT Extensive Reading SIG invites you to:

The 8th Annual Extensive Reading Seminar What is Extensive Reading?

Seinan Jo Gakuin University, Kitakyushu

Sunday, June 21, 2015.

For more information:

http://jalt.org/er/events 